Espacio, Tiempo y Forma, Serie IV, H. Moderna, t. V, 1992, págs. 31-50

\title{
España, frontera de la modernidad
}

\author{
RAFAel Rojas
}

En su Introducción a la Ética protestante y el espiritu del capitalismo, Max Weber intentó precisar los rasgos únicos e irrepetibles de la racionalidad occidental. Partiendo de la certeza de que procesos como la extensión del cálculo de beneficios a todas las actividades humanas, la centralidad de las relaciones monetario-mercantiles o la emergencia de un Estado burocrático con voluntad de legitimación jurídica y política se debian a una lógica propia de la historia europea, Weber, sin proponérselo, no hizo más que fijar los límites espaciales de la cultura moderna.

En la Introducción, el reverso comparativo de la modernidad europea se sitúa en las culturas orientales y mediorientales, siguiendo la herencia del racionalismo metafísico alemán. Sin embargo las tesis sobre el papel de la ética protestante en la formación del capitalismo moderno establecen márgenes dentro del propio espacio occidental. La idea de Weber se apoya en el hecho de que los paises que sufrieron el rigor de la religiosidad puritana entre los siglos XVI y XVII, poseían a principios del siglo XX las estructuras más definidas de la modernidad occidental ${ }^{1}$.

La afirmación ascética de la vida, la perspectiva crematológica del mundo y la verificación de la fe en la práctica profesional permitieron a las sociedades protestantes, según Weber, sustituir el poder formal de la Iglesia por un modo de intervención casi absoluto en todas las esferas de la vida pública y privada. Sometierido a regulación onerosa y minuciosa la conducta económica individual, la nueva doctrina se constituyó en freno y moderación del impulso lucrativo y propició un espíritu de ganancia re-

"Aunque la Ilamada "tesis de Weber" sobre el papel de la ética protestante en la génesis del capitalismo ha tenido algunas refutaciones, es bastante reconocido el hecho de que, con la formación de la economía mundial en el siglo xvi, el centro dinámico del comercio, las finanzas y las manufacturas se traslada del Mediterráneo a los Países Bajos, es decir se traslada del mundo católico al mundo protestante. Ver HILL, Christopher, «El Protestantismo y el desarrollo del capitalismo", en Estudios sobre el nacimiento y desarrollo del capitalismo. Madrid, Editorial Ayuso, 1978. 
novada y cálculo dinerario. Claro está que Weber no mide la mayor o menor intervención de cada una de las culturas europeas en la Reforma, pero sí valora la simpatía que despierta la ética reformista en las élites industriales y comerciales de los Paises Bajos, Inglaterra y algunas zonas de Francia y Alemania. Finalmente destaca el hecho de que los Estados Unidos se hallan fundados sobre las sólidas bases de una moralidad protestante.

Aunque en el texto de Weber no hay una jerarquización de la modernidad a partir de los rasgos de las naciones europeas -enfoque clave de la sociología eugenésica y de la teoría de los genios nacionales (Arthur de Gobineau, H.S. Chamberlain, Vacher de Lapouge, entre otros)- sus tesis contienen una versión negativa. Si se corren los grandes movimientos que permitieron la cristalización de la racionalidad moderna en las instituciones sociales: Renacimiento, Reforma, Estado Clásico, Revolución Industrial, Ilustración, Revolución Burguesa, Estado Moderno, se observa que Rusia y la Europa del Este, de un lado, Portugal y España, del otro, tuvieron una participación escasa o sui generis en ellos. De ahí que la modernidad, desde la perspectiva weberiana, se entienda como la concurrencia de ciertos efectos renovadores en regiones de alta densidad histórica, y no como un grado mundial que poco a poco va incorporando todos los espacios a la nueva racionalidad.

La idea de la modernidad, como grado mundial, tampoco se encuentra cabalmente en Marx. Es cierto que entre los atributos históricos de la burguesia, Marx destaca, con vehemente entusiasmo, el de la globalización de las tecnologías, los mercados, las comunicaciones y las conciencias. Marshall Berman, tomando una frase alegórica del Manifiesto Comunista, simboliza a la modernidad burguesa con un torbellino planetario en el que «todo lo sólido se desvanece en el aire» ${ }^{2}$. Sin embargo, el modelo marxista del capitalismo se construye sobre la referencia histórica de tres revoluciones: la industrial inglesa, la política francesa y la folosófica alemana. De ahi que, al igual que la weberiana, la representación marxista de la modernidad fije límites espaciales. Quizás en la tradición historiográfica braudeliana, en los trabajos de Inmanuel Wallerstein, Samir Amin, Gunder Franck y en la teoría latinoamericana de la dependencia, se halle la visión de la modernidad más aproximada a la de un sistema horizontal que penetra a través de mecanismos endógenos o exógenos las instituciones de todas las sociedades ${ }^{3}$.

\footnotetext{
${ }^{2}$ Berman, Marshall, Todo sólido se desvanece en el aire. México, Siglo XXI, 1989.

${ }^{3}$ Wallerstein ha distinguido tres formas de interpretar los orígenes económicos de la modernidad. Una es la que localiza el arranque de la modernidad en la Revolución Industrial
} 
Probablemente el capitalismo moderno gravita en la mentalidad europea desde la Baja Edad Media. Pero no es sino hasta el período que va del Renacimiento a la llustración cuando la modernidad alcanza lo que Jürgen Habermas llama el «autocercioramiento" ${ }^{4}$, es decir, la conciencia de que se está experimentando el reacomodo de los sujetos y las instituciones a un nuevo orden de valores. Desde este momento se hizo recurrente el hecho de que las modas cortesanas, los paradigmas filosóficos, los sistemas políticos, las estrategias económicas y los estilos artísticos conformaran códigos de civilización y se dictaran desde Francia, Italia, Inglaterra o Alemania para el resto de Europa. Asi, la sumisión tópica del Medioevo, que se ejercia desde las autoridades escolásticas y los arquetipos cristianos, se vio desplazada por la sumisión paradigmática de modelos culturales contemporáneos. Permanecer al margen de ciertas pautas modernas representó para muchas naciones el peligro de verse afectadas por politicas de alianzas globales. Algo asi le sucedió a España, desde mediados del siglo XVIII hasta la pérdida de todos sus territorios coloniales, en las disputas por el dominio comercial y militar del Atlántico con Inglaterra y los Estados Unidos.

\section{EL IMPERIO DE LA CRISTIANDAD}

España es uno de esos países que, por lo general, se localizan en los márgenes de la modernidad. Se alude con frecuencia al espiritu de cruzada, a la Reconquista, al arraigo de la figura del caballero cristiano en la tradición hispánica, a la Inquisición, a la Contrarreforma, a los Autos de $\mathrm{Fe}$, y se asocia la mentalidad ibérica a un visceral sentido del honor, la gloria y la recompensa. En términos politicos se señala la imperfecta integración del Reino, la insuficiente secularización y la persistencia de una imagen monárquico-patrimonial del poder. La economía española aparece siempre vinculada a los monopolios, a las protecciones, al hermetismo mercantil, a la fiscalización excesiva y a los privilegios esta-

(Cipolla, Coleman, Balibar, Clark). Otra es la que encuentra los orígenes de la modernidad a lo largo del siglo xvi (Simiand, Sweezy, Braudel, y es, al parecer, la que asume el propio Wallerstein). $Y$, por último, otra forma que se remite al racionalismo del siglo xvII, para ver en la «matematización del mundo» el primer proceso moderno (ChaUnu, Hobsbawm). Ver WaLLERSTEIN, Inmanuel, El moderno sistema mundial, II: El mercantilismo y la consolidación de la economia-mundo europea 1600-1750. Segunda edición. México, Siglo XXI editores, 1984, pags. 8-11. na 11.

Habermas, Jürgen, El discurso filosófico de la modernidad. Madrid, Taurus, 1989, pági- 
mentales. En cuanto a la cultura, todos los signos hispánicos tienden a resolverse entre la picaresca y el misticismo cristiano, entre la ilusión quijotesca y la errancia teresiana.

Estas representaciones del mundo hispánico configuran un estereotipo de antimodernidad que se forma sustancialmente en el siglo xv. Para España, éste será un siglo de definiciones últimas. En su curso se realizará y se quebrará la idea imperial de la cristiandad. $Y$ lo que es más significativo aún: durante este siglo, en el que debia articularse el tránsito de la Edad Media a la Edad Moderna en la sociedad española, el Imperio asume la empresa del descubrimiento, conquista, evangelización y colozanización de la mayor parte del continente y las islas americanas.

La historiografía contemporánea, a través de las obras de Pierre Chaunu, Pierre Vilar, Joseph Pérez, Henry Kamen, J. H. Elliott y John Lynch, entre otros, ha reparado en el hecho de que la vía española a la modernidad, abierta por los Reyes Católicos a finales del siglo xv, se cierra alrededor de 1595 cuando los fracasos de la Armada Invencible, la alianza de Francia, Inglaterra y Holanda, las constantes rebeliones por la autonomía de los Países Bajos y la crisis constitucional provocada por la revuelta de Aragón, anunciaban ya la declinación de la hegemonia del Imperio. Estas interpretaciones, por lo general, identifican el absolutismo de los Habsburgo con un esplendor que, si bien por razones estructurales, era ficticio, justificaba un proceso de expansión económica y política muy acelerado para la época. De modo que, al verificarse la pérdida de territorios, los obstáculos que otras naciones establecen a la expansión hispánica y la crisis financiera del Imperio, se concluye que el proceso modernizador ha quedado interrumpido.

La idea de la decadencia del Imperio aparece acompañada de varios factores, como la inflación generada por los metales americanos, el endeudamiento de la Corona, el descuido de la unidad de las provincias españolas, la extensión de los estatutos de linaje, etc. Estos factores quedan envueltos en el espíritu de la Contrarreforma y se presentan muchas veces como obra de la fatalidad medieval de la tradición española. Los orígenes de esta fatalidad se encuentran en aquellos largos siglos de Reconquista, en que la figura del caballero cristiano se granjeó honores desterrando a judios y musulmanes. De aquí resulta que en la historiografía hispanista se proponga la imagen de un ciclo arcaizante entre la Reconquista y la Contrarreforma, del cual la cultura española salía preparada para abanderar la cristiandad.

Sin embargo, pocas veces se enfocan las dificultades de la transición moderna de España a partir de los efectos internos que debió producir su incorporación, como entidad central, al Sacro Imperio Romano Germáni- 
co. Esta perspectiva ha sido privilegiada por autores españoles como José Antonio Maravall, Luis Bonilla, Ramón Grande y Antonio Domínguez Ortiz. En ellos actúa la voluntad de ponderar las primeras formas de desfeudalización -coincidentes en el tiempo con las institucionalizaciones modernas iniciales en Inglaterra, Francia y Venecia- que experimentó la política de los Reyes Católicos y a las que fueron renunciando los propios Reyes en los umbrales del Imperio, y los Habsburgo durante el siglo XVI.

Es innegable que, más allá de los artilugios dinásticos, la vocación imperial de España se fue fraguando durante el reinado de Fernando e Isabel. A principios del siglo XVI el humanista Antonio de Nebrija, quien se esforzó por otorgarle a la lengua castellana un rango imperial, observaba: «aunque el título del Imperio esté en Germania, la realidad de él está en poder de los reyes españoles, que, dueños de gran parte de Italia y de las islas del Mediterráneo, llevan la guerra a África y envían su flota, siguiendo el curso de los astros, hasta las islas de los Indios y el Nuevo Mundo" ${ }^{5}$. España, como pensaba también Francisco Jiménez de Cisneros, merecía el Imperio.

Pero, a la vez, el Reinado Católico impuso una racionalidad de Estado al desenclave territorial de los señoríos, que sólo podía basarse en un proyecto de nación. Durante el siglo xv la aristocracia castellana había acumulado mucho poder económico y político, derivado de su intensa participación en la Reconquista. Por momentos los nobles castellanos abrigaron la idea de constituirse en autoridad independiente, impulsando cambios dinásticos y ganándole territorios a la Corona. Los Reyes se apoyaron en instituciones medievales como las Órdenes Militares de Santiago, Calatrava y Alcántara, y las Hermandades, para limitar las atribuciones de la aristocracia. A través de una burocracia profesional, compuesta sobre todo por clérigos y letrados, la Corona fomentó la nobleza real que debia ejercer un estricto control fiscal y juridico sobre la nobleza señorial. Se declararon ilegales las guerras privadas, se restringieron las maniobras de los adelantados o gobernadores de frontera, se derrocaron algunos castillos feudales con la fuerza de las ciudades, etc. Esta racionalidad estatal mereció, en la figura de Fernando el Católico, los elogios del fundador de la teoría política moderna, Nicolás Maquiavelo.

La política de unificación de las Coronas españolas sobre estas bases, se vio afectada cada vez que los conflictos con la aristocracia alcanzaban cierta gravedad. Así, con las Leyes de Toro, del año 1505, los soberanos

\footnotetext{
${ }^{5}$ Kamen, Henry, Una sociedad conflictiva: España, 1469-1714. Madrid, Alianza Editorial, 1984, pág. 29.
} 
otorgaron grandes prerrogativas a los mayorazgos y a la Mesta, reconociendo de esta forma los intereses de los señorios, pero afectando considerablemente la agricultura y la industria del paño. No obstante, tampoco debe exagerarse la modernización de los Reyes Católicos presentándola como una auténtica desfeudalización.

Henry Kamen ha expuesto un argumento curioso contra la tesis de la desfeudalización, para el caso de Castilla. Según su idea la falta de autoridad real que desató la política de los Reyes Católicos en Castilla se debía, más que a tensiones entre señoríos locales, a una «ausencia virtual de feudalismo" " Kamen argumenta que la repoblación cristiana del Duero se llevó a cabo por nobles guerreros que actuaban con independencia de la Corona. Los territorios reconquistados se convertían, por tanto, en señorios al margen de los feudos reales, que el autor llama «pequeñas propiedades». Quizás en la idea de Kamen gravite la intención de presentar la Reconquista, en ciertas regiones de España, como un proceso parecido al de la expansión territorial de los fronterizos norteamericanos. Pero esto podría conducir a verdaderos absurdos históricos.

Si nos apoyamos en la definición de la sociedad feudal que elaboró Marc Bloch, a partir de las relaciones de vasallaje que se articulan dentro de un régimen señorial ${ }^{7}$, nos percatamos de que el enlace o desenlace de la nobleza con la autoridad monárquica resulta secundario. De modo que la Reconquista, por el sistema de dominio que aplicó a las poblaciones infieles, fue un fenómeno propagador de las instituciones feudales. Al nivel de las mentalidades, la Reconquista consolidó el arquetipo del caballero cristiano que había sido la figura central de las Cruzadas. La guerra santa y la errancia se fijaron como atributos casi inamovibles en la sociedad española. Esto se nos hace aún más significativo si valoramos el peso de la cultura bucólica y pastoril en la tradición hispánica. El pastor, como el caballero y el misionero, rechaza el orden sedentario y la reconcentración espacial que caracterizan las evoluciones sociales modernas.

Sin embargo, el hecho de que la figura del caballero cristiano, fundada en las Cruzadas y la Reconquista, reaparezca más tarde en la Conquista de América y sea el ideal de San Ignacio de Loyola al concebir la Compañía de Jesús, no significa que la Reconquista, la Conquista de América y la Contrarreforma hayan sido manifestaciones de una antimodernidad congénita de la cultura española. Esta manera, tan común, de interpretar

\footnotetext{
${ }^{6}$ Ibidem, pág. 32.

${ }^{7}$ Bloch, Marc, La sociedad feudal. Madrid, Ediciones Akal, S. A., 1986, pág. 252.
} 
la historia de España oculta los efectos que produjo en esa nación aún dispersa el tener que encabezar un proyecto de Imperio universal.

Según Chaunu, todos los acontecimientos que fomentaron en España el sentido temporal y espacial de frontera de la cristiandad -entre los que sobresalen la Reconquista y el Descubrimiento de América- a la muerte de Fernando el Católico, actúan como antecedentes del proyecto imperial. Chaunu vincula la definición de los estatutos de sangre con la represión de los alumbrados y las corrientes erasmistas, y propone que estos dos procesos sean comprendidos en virtud de la afirmación de la idea del Imperio Cristiano. En tal sentido señala:

"el movimiento de los estatutos de pureza de sangre es, en cierto modo, la reinterpretación popular de una ideologia aristocrática sobre la frontera de la cristiandad, en la que las diferencias sociales son evaluadas por unas oposiciones de sistemas de cultura, de sensibilidad y de religión, y finalmente la federación de toda una sociedad en una misma búsqueda de una pureza imposible en el mismo temor a una impureza que procedería del linaje ${ }^{8}$.

Chaunu construye esta curiosa interpretación a partir del campo que abrieron dos célebres ensayos: Les controverses des statuts de "pureté de sang» en Espagne du xve au xvile siècle, de Albert. A. Sicroff, y Erasmo y España, de Marcel Bataillon. Según su enfoque, la obra de Sicroff trata en el orden de la sensibilidad social la misma circunstancia que Bataillon describe en el plano intelectual. Es decir, después de la Reconquista la sociedad española debia resolver su integración marginando y excluyendo todos los signos culturales que no fueran representativos de las regiones cristianas. En ese caso se vieron las tradiciones judias y musulmanas, y el primer paso para su decantación fue la limpieza de sangre. En la esfera de las creencias, como correlato de la identidad racial, la Inquisición, de acuerdo con el sentido que le dieron los Reyes Católicos, debía propender al reconocimiento de todos los pueblos hispanos en una misma doctrina.

Chaunu observa que, con el Imperio, estos dos procesos concomitantes se aceleran y hacia mediados del siglo XVI comienzan a dar señales de una cercana crisis. El Imperio nace de un cálculo dinástico: Carlos I es proclamado cogobernante (junto a su madre) de los reinos españoles en Bruselas en 1516. Dos años después tiene su primer encuentro con la

\footnotetext{
${ }^{8}$ Chaunu, Pierre, La España de Carlos V. Barcelona, Ediciones Península, 1976, pág. 154.
} 
voluntad nacional castellana en las Cortes de Valladolid ${ }^{9}$. Del debate entre las Cortes y el soberano durante este encuentro, podemos interpretar el conflicto entre una lógica nacional de modernización iniciada por los Reyes Católicos y sostenida por los letrados castellanos que rodeaban al Regente Jiménez de Cisneros, y otra lógica imperial de modernización representada por los áulicos flamencos y borgoñones de Carlos I.

Los diputados castellanos, en una actitud típica de la tradición política española, comenzaron recordándole a Carlos I en Valladolid que sus poderes estaban limitados por el cogobierno con la reina Juana. Más adelante exigieron reformar la Inquisición, se pronunciaron por un racional control sobre la exportación de metales preciosos y por la disminución de los impuestos fiscales (por entonces fray Alonso de Castrillo, en su Tratado de la República, ya condenaba al fracaso las economías basadas en los ingresos fiscales). Las Cortes advirtieron al monarca que se opondrían al predominio de extranjeros en los cargos de la administración real que se debía garantizar una mayoría castellana en las instituciones politicas. Finalmente, decretaron que el Rey debía hablar castellano y abrieron el pacto de gobierno ${ }^{10}$.

El encuentro con los castellanos en las Cortes de Valladolid persuadió a Carlos I de que debía detener la incorporación de flamencos y borgoñones al gobierno imperial. En dos años se habian concedido múltiples feudos, títulos y cargos públicos a nobles cercanos del poder dinástico. Entre estas concesiones figura el efímero feudo de todo Yucatán y Cuba, que recibió el saboyano Laurent de Gorrevod en 1518, junto con la primera licencia para la trata de negros esclavos con destino a América.

Paralelas a la castellana surgen las primeras reacciones aragonesas y catalanas ante el proyecto imperial. El ambiente se va cargando, au-

\footnotetext{
${ }^{9}$ Desde Valladolid, la circunstancia imperial de Carlos $\mathrm{V}$ apareció unida a una serie de contradicciones formales que en cierta medida lo obligaron a actuar cautelosamente. En palabras de Menéndez Pidal, estas contradicciones o «situaciones confusas» se resumen en que se trataba de uun rey de España que sube al trono sin poder hablar español. Un emperador que se dice señor de todo el mundo y no es obedecido siquiera por Alemania; que lleva por título rey de romanos y es elegido únicamente por alemanes; que no es cabal emperador si no es coronado por el Papa y que no manda en las tierras del Papa". MENENDEZ PIDAL, Ramón, Idea Imperial de Carlos V. Madrid, Espasa-Calpe, S.A., 1963. (Colección Austral, 172), pág. 13.

10 Las presiones sobre Carlos V y su capacidad para asimilarlas presentaron una imagen del emperador muy cercana al ideal monárquico expresado por Isabel la Católica en su testamento. En Valladolid y en las Cortes de la Coruña en 1520, Carlos V pareció estar dispuesto a retroceder la soberanía y a identificar la naturaleza sagrada del monarca con una suerte de sublime servilismo al pueblo y a las cortes. Esto, al decir de Menéndez Pidal, provocaba una inversión del trato entre el señor y los súbditos muy efectiva. Op. cit., página 15.
} 
mentan las tensiones entre el Rey y las Cortes, se registran levantamientos de nobles y, finalmente, en 1520 estalla el movimiento de las Comunidades. Las demandas de los comuneros expresadas en la Junta de Tordesillas demuestran, como las de los diputados de Valladolid, que en las ciudades la política de los Reyes Católicos había afianzado el compromiso con un proyecto nacional. Proyecto que los comuneros veían en peligro con las nuevas condiciones que impondría el Imperio.

En esta situación límite la aristocracia castellana optó por el proyecto imperial y se convirtió en la artífice del enfrentamiento a los comuneros. La victoria de la caballeria de la aristocracia castellana sobre Padilla en la aldea Villalar marcó en gran medida el desplazamiento del proyecto nacional de modernización por el proyecto imperial. La represión que sobrevino contra levantamientos comuneros aislados reafirmó a Carlos I en el poder. Después de sofocadas las rebeliones, el monarca se permitió desarrollar una política más o menos benefactora hacia las ciudades.

Decidida ya la suerte del Imperio, y colocada España en un forzoso liderazgo político sobre Europa, apareció en Alemania el mayor peligro de división religiosa de Occidente. Mientras Carlos $V$ confirmaba su poder en España, Lutero mandaba a fijar en las puertas de la catedral de Wittenberg las 95 tesis en latín que dieron lugar a la Reforma. En el mismo año en que los comuneros eran definitivamente derrotados, Lutero recibía la bula papal de excomunión vitalicia. Esto indica que el Imperio, apenas erigido sobre las resistencias nacionales españolas, tuvo que enfrentar el cisma luterano en calidad de representante político de la cristiandad europea.

Sin embargo, el paso de un frente a otro no fue tan brusco. Durante los años 20, dando continuidad a los esfuerzos renacentistas de Reforma eclesiástica emprendidos por Cisneros, florecieron en España alternativas extracuriales: algunas místicas, como la de la secta de los alumbrados, y otras doctrinarias, como la corriente erasmista. El iluminismo alcanzó una amplia difusión entre las órdenes mendicantes y el clero regular por cuanto propiciaba una reforma monástica. El recogimiento, el abandono, la ascensión mística y el rechazo a la rigidez sacramental que sugiere el Tercer Abecedario Espiritual de Francisco de Osuna, divulgó las prácticas alumbradas, sobre todo entre los franciscanos. Algo del misticismo iluminista trasladan los primeros misioneros franciscanos a América, y esto, en cierto modo, permite explicar las contradicciones que pronto aparecieron entre el clero regular y el clero secular, y entre las diferentes órdenes, durante la evangelización.

Las conexiones entre el misticismo alumbrado de principios de siglo y el misticismo contrarreformista posterior al Concilio de Trento, son evi- 
dentes. En cuanto a esto, se conoce el hecho interesante de que San Ignacio de Loyola, futuro fundador de la Compañia de Jesús, fue encarcelado en 1527 y sometido a tres interrogatorios por sus inclinaciones iluministas. Pero es necesario precisar que, aunque haya actitudes y fórmulas muy parecidas entre uno y otro, el primer misticismo se inscribe dentro de la tradición reformista del Renacimiento español -en la que se incluyen los debates entre observantes y conventuales, el impulso que dio Cisneros a la imprensión de obras devotas de Savonarola, Vicente Ferrer y Catalina de Siena, la fundación de la Universidad de Alcalá, la edición de la Biblia Políglota Complutense, etc.-; mientras el misticismo contrarreformista, a excepción quizás del que profesaron los poetas de la vía unitiva Fray Luis de León, San Juan de la Cruz y Santa Teresa de Jesús, responde a la necesidad de una alternativa imperial a la reforma luterana. Aqui volvemos a encontrarnos frente a la hegemonía de la idea imperial cristiana sobre las corrientes espirituales hispánicas.

El movimiento erasmista, a diferencia del iluminismo, influyó sobre todo en el clero secular y en la nobleza real. Luego de la publicación de su Nuevo Testamento, Erasmo fue invitado por Jiménez de Cisneros a visitar España. Alfonso de Fonseca, arzobispo de Toledo, le ofreció una pensión de 200 ducados de oro. Alfonso de Manrique, arzobispo de Sevilla e Inquisidor General, demostró sobradas simpatías por la doctrina erásmica. Pronto los más brillantes intelectuales españoles (Vives, los hermanos Valdés y otros) al ver que la doctrina gozaba de buena reputación en la Corte y el Clero, se convirtieron en traductores e intérpretes de Erasmo.

Comúnmente, este entusiasmo por la obra de Erasmo en España durante la década de los 20 del siglo xvı se explica por dos razones. La primera señala que en la vuelta a la filosofía de Cristo que proponían las obras de Erasmo, y en particular en su Instituto Principis Christiani, el Emperador Carlos $V$ y sus asesores creyeron hallar una nueva fuente de legitimación del Imperio Universal de la Cristiandad. La segunda razón sugiere que desde que Erasmo se opuso a Lutero sobre la cuestión del libre albedrío en 1521, los españoles encontraron en la doctrina erásmica una tercera vía para resolver la polémica entre la Reforma y el Papado.

Además de estas dos razones, se debe señalar que hacia 1525 la idea del Imperio cristiano había tropezado con las resistencias del papa Clemente VII y del rey de Francia Francisco I, quienes, junto a los príncipes alemanes protestantes, estuvieron dispuestos a la alianza con los turcos por limitar el creciente poder de los Habsburgo. Carlos V estaba, como los principes medievales de la guerra de las Investiduras, obligado 
a disputarse con el Papado el dominium mundi en nombre de Cristo ${ }^{11}$. El Papa condenaba a Erasmo, sobre todo a partir de la publicación del Enchiridion o Manual del caballero cristiano, de modo que la aceptación de esta doctrina en España puede considerarse como una demostración de fuerza del Emperador.

La rivalidad provocó actos políticos insólitos como el saqueo de Roma. La Corte de Carlos $V$ comprendió que debía pasarse a una actitud conciliatoria. Este cambio de actitud se expresó en la paz de Cambrai, en la Dieta de Augsburgo y en la Coronación imperial de Bolonia. Los edictos inquisitoriales contra los alumbrados y la represión del erasmismo no se hicieron esperar. En 1530 la sociedad española estaba liberada de toda alternativa doctrinaria a la Iglesia Católica, y el Imperio decidido a hacer las paces con el Papado. La mejor prueba de esta política fue el Concilio de Trento iniciado en 1545, el cual elaboraría los principios de la Contrarreforma.

Este proceso histórico entraña un complejo fenómeno de transfiguración política. Es decir, siguiendo la historia de España en la primera mitad del siglo XVI se observa cómo un movimiento endógeno de integración y unificación nacional - con rasgos bastante parecidos a los de la modernización y secularización que tienen lugar en otros países de Europacomienza por tomar carácter expansivo y exclusivo con la colonización de América y la Reconquista, y termina por representar un movimiento exógeno basado en el ideal de frontera de la cristiandad. La confrontación con los judios, los musulmanes y los indios americanos se transfiguró en

\footnotetext{
11 En una magistral conferencia dada en 1937 por Ramón Menéndez Pidal en la Institución Hispano-Cubana de Cultura, de La Habana, titulada La Idea Imperial de Carlos V, se destaca el carácter englobador de la cristiandad que poseía el Imperio. Menéndez Pidal contrapone a la «idea imperial» carolina, interpretada por Karl Brandi, otra filosofia del Estado expuesta por los consejeros del Emperador antes del saqueo de Roma y del célebre discurso del 16 de septiembre de 1528. Según su enfoque, Brandi describe la concepción del imperio carolino que aparece en las Memorias del canciller Mercurino Gattinara, quien a su vez había asesorado políticamente a Carlos $V$ siguiendo el modelo de Dante en De Monarchia. Esta concepción enfatizaba la expansión territorial y la conquista militar de "otros» reinos, como actos de confirmación de la hegemonía mundial. Menéndez Pidal pondera, en cambio, una idea imperial expuesta ya en la declaración de La Coruña, redactada por el doctor Ruiz de la Mota, y reiterada en la Dieta de Worms, según la cual cla efectividad principal del Imperio no es someter a los demás reyes, sino coordinar y dirigir los esfuerzos de todos ellos contra los infieles, para lograr la universalidad (cristiana) de la cultura europea" (op. cit., pág. 19). En este sentido quedan enfrentadas dos filosofias imperiales: una, que resalta la condición de rey de reyes del emperador romano-germánico a partir de su dominio efectivo sobre todos los reinos, y otra que ve en dicha condición un poder moderador de la cristiandad, capaz de conformar alianzas ofensivas y defensivas frente al mundo no cristiano. Esta última concepción colocaba al emperador en una posición muy parecida a la del papa. De ahí uno de los motivos de contradicción.
} 
confrontación con los protestantes. Pero, si en la primera los cristianos actuaban en nombre de España, en la segunda ya representaban a un Imperio de alcance universal.

Los efectos de esta transfiguración política en la cultura española son constatables en el plano del discurso. Como correlato de los movimientos de oposición al proyecto imperial (los alumbrados, las comunidades, los agermanados de Valencia) se articula un discurso político y jurídico de fundamentación teológica que, lejos de propiciar -como habitualmente se piensa- el soporte teórico del Imperio, supone su deslegitimación. Desde la perspectiva política, este discurso propone un sistema monárquico-democrático basado en el pacto entre el Rey y los súbditos. La idea del pactum trans/ationis, que aparece en los escritos de Castrillo, de Mariana, de Morcillo y de Suárez, ofrece una alternativa a la teoría política moderna que se funda en la tradición de Locke y Rousseau. Pues, si en la teoría del Contrato Social el ciudadano enajena totalmente su libertad primigenia por acatar los dictámenes de la voluntad general, en la teoría del pactum trans/ationis el súbdito enajena sólo una parte de su arbitrio y condiciona el dominio que se ejerce sobre él a la vigencia del pacto. Asi, cuando las Cortes de Zaragoza juraron fidelidad al Rey en el siglo XVI, declaraban: «Nos, que valemos tanto como vos y juntos podemos más que vos, os hacemos nuestro Rey y Señor, con tal que guardéis nuestros fueros y libertades; y si no, no". Esta soberania sustitutiva de las Cortes fue la que permitió el diseño de una Constitución como la de 1812, orgánicamente enlazada al sistema monárquico-democrático español, ante la abdicación de Fernando VII en Bayona.

En la esfera juridico-teológica el discurso español del siglo xvi elabora la doctrina del derecho de gentes, punto de partida del derecho natural de Grocio y Pufendorf y antecedente de las normatividad juridica internacional. Las Releciones de Francisco de Vitoria y el debate de Valladolid entre Las Casas y Sepúlveda en 1552, indican la resistencia que hace el discurso a la política imperial. Y aunque, en la mayoria de los casos, la política real no toma en cuenta los presupuestos del discurso, ese desencuentro entre política y discurso revela la relativa legitimidad del proyecto imperial.

\section{CONTRARREFORMA Y MODERNIZACIÓN}

La Contrarreforma no fue simplemente la respuesta del catolicismo al cisma luterano, concebida entre 1545 y 1563 en el Concilio de Trento. Fue, 
ante todo, el resultado final de una Reforma originaria del clero español que quedó transfigurada en las condiciones del Imperio. A diferencia del resto de los paises católicos de Europa, en España la Contrarreforma es un espíritu, una actitud mental que riega toda la cultura. Los autos de fe, los sínodos, los edictos inquisitoriales se hicieron rutinarios en la España de Felipe II. En ellos se juzgaba a cualquier persona y sobre cualquier tema, desde un clérigo que había actuado como inquisidor, hasta la cuestión del cambio de la moneda.

Sin embargo, esta sociedad que los místicos carmelitas representan como si estuviera habitada sólo por Dios y las almas, y que la pintura tenebrista, por ejemplo de un Ribera, se figura en forma de mártires patéticos y obispos alargados, no es fundalmentalmente teocrática. Está dominada por un Estado que usa a la Iglesia como instrumento de cohesión y a la doctrina católica como argumento de legitimación imperial. Este Estado, a través de un estricto control del comercio con sus colonias, recibe los metales que necesita para financiar su déficit de manufacturas. $Y$ así, fiscalizando su propio mercado imperial, crea una atmósfera de prosperidad artificial en la que oculta la inflación y el endeudamiento que estructuralmente la afectan.

La frontera de la cristiandad trazada por Carlos $V$ se convierte en frontera de la modernidad con Felipe II. Los paises protestantes, no sólo fueron los enemigos bélicos de España desde el Concilio de Trento hasta la Paz de Westfalia en 1648; fueron, además, los enemigos morales y económicos, los más acérrimos críticos y los más inflexibles acreedores. Muchos de estos países desprendidos del propio Imperio incorporarían a su cultura la imagen de la antimodernidad española como una afirmación del rumbo civilizatorio que escogian para sí mismos.

La relación proporcional entre Reforma y Modernidad y entre Contrarreforma y Antimodernidad se establece en la mentalidad europea desde este momento. Como veremos más adelante, los diseñadores de la imagen antimoderna de España fueron sus enemigos protestantes de los Países Bajos. De la ideologia de la Reforma, esta imagen pasa a la ideologia de la llustración. El proyecto de modernidad que trazaron los ilustrados, aunque fundado sobre valores y razones universales, se inspiraba en instituciones políticas y económicas alcanzadas sólo por ciertos países. Ya desde entonces, Occidente se dividia en zonas que llegaban a la modernidad por vía natural y endógena y zonas que debían ser modernizadas. Napoleón, en sus campañas militares, actuaba convencido de que modernizaba los territorios que incorporaba al Imperio. 
Alain Touraine ha analizado en detalle la diferencia conceptual entre modernidad y modernización ${ }^{12}$. Tomando como referencia toda la sociologia de la transición del status tradicional al moderno (Spencer, Durkheim, Simmel, Tönnies, Weber), Touraine observa que, a finales del siglo XIX, algunas sociedades entraban en la modernidad empujadas por una mecánica cultural que las habia hecho sensibles a la renovación tecnológica, al utilitarismo, a la ponderación de la iniciativa personal y a la expansión de la industria y el comercio, mientras otras lo hacían violentadas por una racionalidad estatal intensa que las entregaba a una suerte de cálculo de las posibilidades de renovación y progreso que podian obtener en cada jugada política. En el primer caso Touraine incluye a Inglaterra, Francia y los Estados Unidos, en el segundo a Alemania, Italia, Japón y la Turquía kemalista.

Según Touraine, después de la primera Guerra Mundial, estos procesos se intensifican debido a la creciente intervención estatal en los asuntos económicos. $Y$ es precisamente en esta etapa cuando surgen los primeros modelos de contramodernización: el caso más evidente es el de la Unión Soviética. Nótese que cuando Touraine habla de «contramodernización», no se refiere a la antimodernización, sino a un camino acelerado hacia la modernidad que se transita negando el eje individual de acumulación y legitimación del capitalismo moderno. La antimodernización, de acuerdo con su idea, aparecerá más tarde en algunas lecturas casi místicas de Marx empeñadas en anular las relaciones monetario-mercantiles de economías dependientes, como el caso de la China maoista y los experimentos del Che Guevara en Cuba durante los años 60.

Pero la idea de Touraine, que nos permite abordar la circunstancia de España, es la que enuncia el sentido violento de toda modernización frente a las especificidades culturales. En la situación de paises multinacionales y paises coloniales, la modernización instrumentada desde el centro o desde la metrópoli siempre implica un desmontaje racional de la identidad. Rencientemente esta idea ha sido defendida por Isaiah Berlin ${ }^{13}$. En su opinión, los nacionalismos actuales que convulsionan a Europa Central son las revanchas de identidades históricas agredidas por la práctica de un proyecto supuestamente universal de contramodernización. Los nacionalismos latinoamericanos, los asiáticos y los africanos responden a la misma reacción ante las modernizaciones coloniales.

\footnotetext{
12 TOURAINE, Alain, "Modernidad especificidades culturales» Revista Internacional de Ciencias Sociales, vol. 40, núm. 4, nov. 1988, págs. 469-476. 17.

13 Berlin, Isaiah, "Nacionalismo bueno y malo», Vuelta, 183, febrero de 1992, págs. 13-
} 
En el fondo de esta idea subyace la crítica al modelo de racionalidad occidental y al proyecto ilustrado de modernidad. Ya Adorno y Hokheimer, en Dialéctica de la llustración, concluían que el mensaje final de las Luces era totalitario. La sustitución de la racionalidad instrumental por una racionalidad emancipatoria que reivindicara las especificidades culturales y ponderara múltiples caminos hacia múltiples modernidades fue la proposición clave de la Escuela de Frankfurt. Actualmente, el debate sobre la postmodernidad ha resaltado la necesidad de encontrar sistemas de comunicación alternativos a los códigos homogéneos que impone la tecnología moderna. Sin embargo, el modelo occidental de modernidad no se apoya fundamentalmente en la mundialización de la tecnología -que en resumidas cuentas, como lo demuestra el caso de Japón, puede conciliarse con un sistema de cultura no occidental- sino en la supuesta validez universal de un criterio único de racionalidad política y económica.

Las críticas al proyecto ilustrado de modernidad provocan necesariamente un cuestionamiento de la tesis weberiana sobre las correspondencias Reforma-Modernidad, Contrarreforma-Antimodernidad y una recuperación de los espacios que la filosofía de dicho proyecto ha colocado más allá de los márgenes y las fronteras modernas. Uno de esos espacios históricos a recuperar es España y las alternativas que se obtienen de su experiencia suponen una versión negativa, no ya del régimen excluyente de colonización anglosajona o de la rigidez moral puritana, sino de la propia tradición política europea.

Con más razones se hace esta recuperación si se sigue el recorrido de la imagen antimoderna de España a través de la ideología reformista, hasta llegar a la Ilustración. Rómulo Carbia, en un texto afectado por la excesiva pasión hispanista, ha dado cuenta de este itinerario ${ }^{14}$. Según sus rastreos, hacia 1567, en medio del levantamiento de los Países Bajos, la represión del duque de Alba y la posterior sublevación del príncipe de Orange, los impresores holandeses De Bry realizaron las primeras ediciones extranjeras de la Brevísima Historia de la Destrucción de las Indias de Las Casas. Estas ediciones se hacian acompañar de grises grabados donde se presentaba un tremebundo cuadro de la conquista, con matanzas multitudinarias de indios, fosas colectivas, piras humanas e infinidad de ahorcados. Las caricaturas políticas de la época representaban a los españoles como asnos incapaces hasta de rebuznar, oligofrénicos

\footnotetext{
${ }^{14}$ Carbia, Rómulo, Historia de la leyenda negra hispanoamericana. Buenos Aires, Ediciones Orientación Española, 1944.
} 
en busca de oro o monjes corruptos, embebidos en alguna oración, mientras anhelan estar en perpetuas bacanales y pantagruélicos banquetes.

Cabría afirmar que tan sólo en los diez años que antecedieron a la paz de Westfalia, el libro de Las Casas fue reeditado en la zona de las Provincias Unidas 26 veces. Las fechas de las reediciones posteriores de la Brevísima Historia en diferentes países de Europa, señalan momentos de contradicciones o conflicto político con España: París 1790, Londres 1812, México 1822, Alemania 1926, etc.

El estereotipo de la antimodernidad hispánica aparece claramente en textos clásicos de la llustración como el Diccionario Histórico-Crítico (1695-1697) de Pierre Bayle, en la voz «América» del tomo I de la Enciclopedia (1751) de Diderot y D'Alembert y en el Tratado de la tolerancia (1763) de Voltaire. A tono con el espíritu ilustrado aparecen las obras sobre la conquista y colonización del Nuevo Mundo de Robertson, de Pauw y Raynal, en donde se considera a la española, como raza y cultura, incapaz de trasladar instituciones progresistas a sus colonias. La obra de Raynal, Historia de los establecimientos ultramarinos de las naciones europeas (1770), traducida al castellano por el Conde de Almodóvar, fanático anglófilo, colaborador de Wellington y enemigo declarado de Fernando VII, se convirtió en un documento de identificación política para los liberales españoles entre 1814 y 1820.

Esto último indica que el estereotipo de la antimodernidad hispánica no sólo tuvo una amplia difusión en los ambientes protestantes e ilustrados de las naciones enemigas de España, sino que siempre formó parte de las proyecciones de los liberales españoles y americanos. Los liberales americanos que intervinieron en la Independencia y luego fundaron los Estados nacionales optaron por el proyecto ilustrado de modernidad que veían condensado en la joven república norteamericana. Dentro de esta opción figuraba lógicamente el rechazo a la antimodernidad española. Bolivar lo dejó expuesto en la Carta de Jamaica y el radical chileno Francisco Bilbao, en El Evangelio Americano, concluyó que la fórmula del progreso «consiste en desespañolizarse». Los liberales españoles de 1812, 1820 y de la generación del 98 se aplicaron una autorrecriminación tan visceral, que la crisis de identidad que desde ellos sobrecogió a la cultura española todavía no ha sido superada del todo.

Pero, para revisar el estereotipo, no basta con antologizar la tradición política, jurídica y económica española y enfrentarla a otras tradiciones nacionales más hegemónicas dentro del espacio europeo. Ante todo, es necesario encontrar en la historia de España las señales de una versión problemática de la modernidad que permita enjuiciar la versión oficial, 
protestante e ilustrada, que aún en nuestros días se sostiene con vehemencia.

Una de esas señales podrian ser los efectos modernizadores, en el sentido ilustrado, de la política de Felipe II en América y en la propia España. Si, como se ha afirmado, con Felipe II España se coloca en la frontera de la cristiandad y la modernidad, resulta paradójico que hacia América la política española se conduzca de acuerdo a una lógica de modernización.

La primera reforma de indole administrativa que realizó Felipe II al recibir la Corona de manos de Carlos V fue depurar el Consejo de Estado. En 1559 esta institución ya estaba despojada de sus miembros no castellanos y en su mayoría compuesta por letrados. El ostensible aumento de la burocracia real con Felipe II fue parte de un nuevo absolutismo legalista, que no tuvo paralelo en la Europa de la época. Las tres universidades de Castilla, Salamanca, Valladolid y Alcalá se consagraron a la formación de una élite de funcionarios que poco a poco fue desplazando de las audiencias, las cancillerías y los consejos gubernamentales a la burocracia de capa y espada, que quedó restringida en su influencia a la diplomacia y la guerra. De las tres oportunidades que regularon la movilidad social en España desde principios de siglo: iglesia, mar o casa real, la tercera se hizo predominante en el reino de Felipe II.

Los letrados o «golillas» fueron dominando gradualmente la realeza y relegando a la aristocracia señorial y el clero. Mientras los nobles recibían los títulos palatinos (mayordomos, gentileshombres, etc.) y las funciones mayestáticas (embajadores, virreyes, capitanes generales, etc.), los letrados reales abarcaban toda la esfera estatal. Esta especie de burguesía profesional -como los funcionarios del reformismo ilustrado del siglo XVIII del estilo de Patiño, Campillo, Ensenada, Campomanes, Floridablanca y Jovellanos, en relación con los «colegiales» aristócrataspenetró los organismos consultivos de la monarquía en calidad de consiliarios y así pudieron reformar la administración. Es decir, desde condiciones y estructuras ancilares a las instancias de la administración monárquica, como visitadores, magistrados y pesquisidores, los letrados se convirtieron en los vehículos burocráticos de la reforma que Felipe II impulsó desde arriba.

La extremada política fiscal a que se vio obligado el Imperio bajo los efectos del endeudamiento con las casas mercantiles de los Fúcares, los Belzares, los Grimaldi, los Doria, los Spinola, etc., necesitaba de una élite burocrática incondicional que la llevara adelante. Los impuestos especiales sobre la saca de la lana, la elevación del porcentaje de las alcabalas y de los derechos de exportación e importación, el embargo del oro y la 
plata de Indias consignados a particulares, la enajenación de señorios, tierras concejiles, títulos de nobleza, regidurías, etc, exigian para su realización de una racionalidad estatal coherente y en cierto modo despiadada.

La plata americana convirtió a España en el intermediario privilegiado para el comercio con las Indias. La necesidad de intercambio con los centros mercantiles y financieros de Europa, el rápido aumento de la capacidad de pago y la inflación hicieron crecer vertiginosamente la masa circulante en el espacio español. Con razón se ha hablado de exceso de liquidez. Esto, sin duda, afectó de un modo particular la conciencia española. El jesuíta Juan de Mariana en su obra De Mutatione Monetae, de 1606, hizo una reflexión teológica sobre el dinero en la que intentaba otorgarle a la moneda el rango de sustancia divina. De modo que, en la sociedad española de Felipe II, la burocracia estatal y las relaciones monetario-mercantiles - signos convencionales de la modernización- habian alcanzado una presencia importante.

Los rasgos ilustrados del absolutismo de Felipe II son conocidos. Se sabe que, con el objetivo de poseer cartas geográficas de todos los reinos peninsulares, contrató los servicios de geómetras, dibujantes, pintores y agrimensores. Ordenó que se tomaran relaciones geográficas, demográficas e históricas de los municipios del pais, con motivo del censo de 1574. Fue un coleccionista maniático de plantas y animales. En Aranjuez estableció un jardín botánico con especies americanas y todo tipo de plantas medicinales. En El Escorial, y también en Aranjuez, atendió personalmente casas de fieras donde se entretenía poniéndoles nombres de personalidades históricas a leones, elefantes, rinocerontes, garzas, etc. Promovió la creación de una Academia de Ciencias Exactas en Madrid, en 1588. Dio órdenes de que se hicieran observaciones del eclipse de sol del año 1557. Mantuvo durante su reinado un archivo oficial de la Corona en el Castillo de Simancas. En fin, la relación podría ser ociosa.

En América, la política de Felipe II otorgó racionalidad estatal a las instituciones de la colonización y la evangelización. Desde el Contrato de Granada firmado por los Reyes Católicos y Colón, y las Capitulaciones de Santa $\mathrm{Fe}$, la intervención del Estado en los asuntos de Indias había sido limitada. El colonizador de América, reencarnando la figura del caballero cristiano de la Reconquista, de acuerdo con las capitulaciones se sentía comprometido con una empresa personal, o en todo caso con una empresa providencial. Las rivalidades entre conquistadores, por ejemplo las que sostienen Velázquez y Cortés, se derivan de esta falta de dirección estatal en la Conquista. 
Las primeras muestras de la voluntad estatal comienzan a aparecer con la Casa de Contratación de Sevilla. En cuanto a la evangelización, que actuaba como factor legitimante de la conquista, los pasos iniciales se dieron con la ayuda de las órdenes regulares. Colón y los primeros conquistadores, entre ellos particularmente Cortés, eran partidarios de que la misión evangelizadora fuera asumida por las órdenes mendicantes. Esto indicaba que los pioneros de la conquista, colonización y evangelización de las Indias preferian mantenerse al margen de las instituciones oficiales, eclesiásticas y estatales.

Las sociedades coloniales se fueron diseñando a partir de una legalidad casuística, de acuerdo con la extrañeza del mundo que se incorporaba al Imperio. Las reducciones de indios y los primeros pueblos, según una cédula real de 1503, requerían para ser construidos y regidos de un administrador español, un capellán y una sujeción tributaria de los vasallos. Esta mínima legalidad se tropezó en la práctica con las innumerables dificultades que implicaban las organizaciones políticas autóctonas, el régimen de producción y distribución, la territorialidad comercial, etc. Los primeros virreyes, en consecuencia, tuvieron cierta libertad de decisión política y jurídica de acuerdo con los casos concretos que surgían en la colonización de sus regiones.

Para el reinado de Felipe II ya se habia acumulado suficiente información sobre las Indias y el Estado monárquico estaba en condiciones de aplicar una política más legalista. En correspondencia con la burocratización que tenía lugar en la península, Felipe II envió visitadores a América con el objetivo de limitar las atribuciones de los virreyes y controlar el sistema fiscal. El visitador Valderrama, en Nueva España, se apoyó en los oidores de la Audiencia para restringir el poder del virrey y de sus colaboradores.

La burocratización trajo aparejada una secularización de las instituciones evangelizadoras. Los seglares comenzaron a hacerse cargo de los curatos y obtuvieron mayor participación en los diezmos. Se establecieron los tribunales de la Inquisición. Las resoluciones del Concilio de Trento se aplicaron a la Iglesia americana, que ya para entonces dejaba de ser aquella Iglesia arcaica y ascética que proyectaron los franciscanos.

Pero quizás la máxima prueba de la racionalidad estatal que el reinado de Felipe II aplicó a los territorios americanos fueron las Ordenanzas de 1573. Con el descubrimiento del sistema de amalgamación en frío por Bartolomé Medina en 1557 la economía americana comenzó a girar en torno a la mineria. De acuerdo con esto el Imperio se vio en la necesidad de elaborar una política poblacional que favoreciera la disposición económica de los territorios. Esta política fue establecida por las Orde- 
nanzas de 1573. A diferencia de las primeras fundaciones de pueblos, improvisadas y casuísticas, en las Ordenanzas se articula un criterio de diseño urbanístico asombroso para la época. En ellas se toma en cuenta para la fundación de ciudades: la selección y orientación del lugar, las posibilidades de iluminación y de provisión de agua, la disposición cuadricular de la traza, la exposición a los vientos, el sistema económico, político y cultural que arrastran los indios que serán concentrados, etc.

Estas prácticas del reinado de Felipe II, más el Protomedicato, las expediciones científicas, las relaciones geográficas y otras, resaltan el carácter ilustrado y modernista de su proyección en América. Los puntos de contacto entre esta política y la de las reformas borbónicas son evidentes. $\mathrm{Si}$, a finales del siglo XVI, España contiene los efectos de una ideología occidental por antonomasia (el protestantismo) instrumentando para sí y para sus colonias una modernización y secularización autónomas, a finales del siglo xvII contiene los efectos de la ideologia ilustrada y burguesa aplicando reformas semejantes. En ambas circunstancias, España se coloca de espaldas a la modernidad occidental para acelerar una modernidad propia en su espacio.

La Contrarreforma de los autos de fe y la Inquisición, de las herejías paranoides y la mística quietista, concilió en su proceso la conciencia de frontera de la cristiandad y la modernidad con una racionalidad estatal absolutista que le permitió impulsar una modernización marginal al interior del Imperio. Esta paradoja, sin lugar a dudas, problematiza la consábida correspondencia entre Reforma y Modernidad.

\section{A MANERA DE CONCLUSIÓN}

De estas reflexiones se desprenden tres sugerencias. La primera es que, en contraposición con el criterio más manejado por la historiografía tradicional, el cierre de la vía española a la modernidad no debe localizarse en la decadencia del Imperio sino en su advenimiento.

La segunda sugerencia se refiere a la necesidad de rearticular las bases conceptuales de la historia de España y América a partir de las críticas al modelo de modernidad occidental, que se han acumulado en los últimos años.

Y la tercera es que, de acuerdo con la relatividad de la tesis weberiana sobre la correspondencia entre la modernidad y la Reforma protestante, se entienda la Contrarreforma española como un proceso cultural capaz de generar una modernización en el ámbito del Imperio y sus coIonias. 